\title{
Empagliflozin: an exciting prospect in the treatment of diabetes
}

\author{
Melvin George $^{1 *}$, Karthik Srinivas $^{2}$, Damal Kandadai Sriram ${ }^{2}$
}

${ }^{1}$ Department of Clinical

Research,

${ }^{2}$ Department of Diabetology \& Endocrinology, Hindu Mission Hospital, West Tambaram, Chennai, Tamil Nadu, India

Received: 12 November 2017 Accepted: 04 December 2017

*Correspondence to:

Dr. Melvin George,

Email: melvingeorge2003

@gmail.com

Copyright: (c) the author(s), publisher and licensee Medip Academy. This is an openaccess article distributed under the terms of the Creative Commons Attribution NonCommercial License, which permits unrestricted noncommercial use, distribution, and reproduction in any medium, provided the original work is properly cited.

\begin{abstract}
Type 2 diabetes mellitus (T2DM) continues to be a chronic and disabling disease that is associated with high mortality and morbidity. The epidemic burden of diabetes mellitus has increased in developing countries and Asia is considered as the "diabetic epicentre". Type 2 diabetes (T2DM), is characterised by reduced secretion of insulin from pancreatic beta cells independently or associated with reduced response of peripheral tissues to circulating insulin. A proper glycaemic control is essential to delay the micro and macrovascular complications of T2DM. Standard anti-diabetic agents including insulin happen to induce minor to major adverse outcomes in certain populations over prolonged period of administration. Hence there has been a compelling need to develop newer and novel approach to treatment of T2DM. Sodium-glucose co-transporter 2 (SGLT-2) inhibitors are a novel category of drugs that happen to reduce glycaemic overload by inducing glycosuria. The safety, efficacy and tolerability profile of these drugs were studied separately under various trials and was approved for use in August 2014 by US-FDA. This review is an attempt to describe the history of SGLT-2 inhibitors, their mechanism of action, safety and efficacy as well as its current status among anti-diabetic agents.
\end{abstract}

Keywords: Complications, Diabetes, Empagliflozin, Efficacy, SGLT2 inhibitors

\section{INTRODUCTION}

Diabetes mellitus type 2 (T2DM) continues to be a chronic and disabling disease, that is associated with high mortality and morbidity. The epidemic burden of diabetes mellitus has increased in developing countries and Asia is considered as the "diabetic epicentre". A whopping $9 \%$ of adults worldwide are affected by T2DM. ${ }^{1}$ Even though several pharmacological treatments, such as sulfonylurea metformin, alpha glucosidase inhibitors and incretin analogues are available for the treatment of diabetes. Each of these drugs have a considerable number of limitations making it imperative that we find better attractive alternatives to improve the glycaemic control of these patients and also reduce drug induced maladies. ${ }^{2}$ Sodium- glucose co-transporter 2 (SGLT-2) inhibitors are a novel class of drugs which reduce blood sugar by inducing glycosuria, a mechanism different from the aforementioned anti-diabetic agents. ${ }^{3}$ This review is an attempt to describe the history of SGLT-2 inhibitors, their mechanism of action, efficacy and safety as well as its current status

\section{Mechanism of action}

Kidneys normally filter $180 \mathrm{~g} /$ day of glucose and hence glycosuria is not typically detected until plasma glucose exceeds $180 \mathrm{mg} \%$. The urine thus filtered normally is negative for glucose. Glucose re-absorption in renal tubules is maintained by 2 types of transporters-Glucose 
transporters (GLUT's), and Sodium-Glucose cotransporters (SGLT's). SGLT's are large family of membrane proteins that transport glucose in brush border of intestinal epithelium and proximal renal tubules using electrochemical sodium gradient as the source of energy generated by $\mathrm{Na}+\mathrm{K}+$ adenosine triphosphatase. ${ }^{4-7}$

SGLT-2 is a high capacity low affinity $\mathrm{Na}+$ coupled glucose transporter in apical part of early proximal convoluted tubule, and it is responsible for $90 \%$ of glucose reabsorption. In contrast SGLT-1 located in distal PCT reabsorbs the remaining $10 \%$ glucose which escaped reabsorption by SGLT-2. SGLT-1 is mainly associated with reabsorption of glucose and galactose in small intestine. Since the mechanism appears to be by inducing glycosuria, SGLT-2 inhibitors are regarded as non-insulin dependent agents of reducing glycaemic overload. ${ }^{6}$

\section{PHARMACOKINETICS}

Empagliflozin is rapidly absorbed in a dose dependent manner, attains peak concentration levels by 1-2 hours and dose dependent increases in urinary glucose excretion was seen up to a dose of $100 \mathrm{mg}$. The terminal elimination halflife of the drug was 13.1 hours. There are no significant food-drug interactions. Around $11.19 \%$ of the drug is excreted unchanged in urine. The maximum plasma concentration of drug was also $20 \%$ higher in subjects with mild or severe renal impairment, compared with normal individuals. Renal clearance and fraction of drug excreted in urine was reduced in patients with decreased renal function. ${ }^{6}$

\section{EFFICACY}

Empagliflozin a sodium glucose co-transporter-2 (SGLT2) inhibitor increases the urinary glucose excretion and improves the glycaemic control through the inhibition of renal glucose re-absorption. Empagliflozin has demonstrated excellent pharmacological and safety profile as an anti-diabetic drug. The other benefits of empagliflozin include weight loss, lower risk of hypoglycaemia, and improvements in cardiovascular outcomes, hypertension and renal complications. ${ }^{8}$

\section{Efficacy of empagliflozin as an anti-diabetic drug}

In a phase III, (EMPA-REG BP) study, the efficacy, safety, and tolerability of empagliflozin (10mg and $25 \mathrm{mg}$ ) was evaluated among patients with T2DM and hypertension. At week 12, empagliflozin showed significant and clinical reductions in $\mathrm{HbA} 1 \mathrm{c}$. The adjusted mean difference in the HbA1c levels between placebo, and $25 \mathrm{mg}$ of empagliflozin was $-0.65 \%(95 \%$ CI $-0.75,-0.55)$ and $10 \mathrm{mg}$ of empagliflozin was $-0.62 \% \quad(95 \%$ CI $-0.72,-0.52)$ respectively (both $\mathrm{P}<0.001) .{ }^{9}$ The safety, tolerability, pharmacokinetics and pharmacodynamics of 10, 25, $100 \mathrm{mg}$ of empagliflozin or placebo was evaluated in T2DM patients for 28 days. The empagliflozin group demonstrated an increase in the urinary glucose excretion up to $90 \mathrm{~g} /$ day, and remained consistent over a 4-week study period without change in urine volume. Fasting sugar was reduced by $30-39 \mathrm{mg} \%$ from baseline by the end of study. Reduction in HbA1c by $0.22-0.36 \%$ was seen in empagliflozin group compared with placebo. ${ }^{10}$ One of the unexpected findings with SGLT-2 inhibitors was an increase in endogenous glucose modulation in part due to increases in glucagon. ${ }^{11}$ Therefore, empagliflozin appears to be an effective anti-diabetic agent.

\section{Efficacy of empagliflozin as monotherapy and combination therapy}

Empagliflozin is a well-established drug for the treatment of T2DM patients. In a multi-national 12-week study, 408 patients were randomized to receive $5,10,25 \mathrm{mg}$ of empagliflozin or matching placebo or open-label metformin. The empagliflozin group showed significant reductions in the HbA1c levels, fasting plasma glucose (FPG) levels and body weight. ${ }^{12}$ In another multicentre, randomised, placebo-controlled, phase 3 trial, T2DM patients were randomized to receive $10 \mathrm{mg}, 25 \mathrm{mg}$ of empagliflozin, sitagliptin $100 \mathrm{mg}$ or matching placebo. The empagliflozin (10 and $25 \mathrm{mg}$ ) and sitagliptin showed a significant reduction in the levels of $\mathrm{HbA1c}$ when compared to placebo. ${ }^{8}$ Empagliflozin has also been studied with other single line anti-diabetic drugs such as oral hypoglycemic agents (OHAs) and insulin. The OHAs include metformin, thiazolidinedione, $\alpha$-glucosidase inhibitor, DPP4 inhibitor, or meglitinide. The combination therapy of empagliflozin with other existing anti-diabetic drugs has been effective in reducing the glycaemic levels. ${ }^{13-16}$ Moreover, the combination therapy has demonstrated no harmful drug interactions. Therefore, monotherapy and combination therapy with empagliflozin is a potential new approach for the treatment of T2DM. However, empagliflozin is yet to be tested against the older molecules such as metformin and sulfonylureas.

\section{Efficacy of empagliflozin on cardiovascular outcomes}

Patients with T2DM have 2.5 times greater risk of developing chronic heart failure (CHF) than the normal subjects. ${ }^{6}$ In the year 2008, the US Food and Drug Administration (FDA) had issued new guidelines which mandated that robust assessments of cardiovascular outcomes are required for the approval of all anti-diabetic drugs in the future. In the comparative effectiveness of cardiovascular outcomes in new users of sodium-glucose cotransporter-2 inhibitors (CVD-REAL) study, SGLT-2 inhibitors were associated with a lower risk of heart failure hospitalization or mortality compared to other glucose lowering drugs. ${ }^{17}$

In the EMPA-REG outcome trial, 7020 patients were randomized to receive 10 or $25 \mathrm{mg}$ of empagliflozin or placebo. The study revealed significant differences in the primary composite outcome (cardiovascular mortality, non-fatal myocardial infarction (excluding silent myocardial infarction), or non-fatal stroke between the 
empagliflozin [490 of 4687 patients (10.5\%)] and placebo group [282 of 2333 patients $(12.1 \%)$ ]. The hazard ratio in the treatment group was $(0.86 ; 95.02 \%$ confidence interval [CI], 0.74 to $0.99 ; \mathrm{P}<0.001$ for non-inferiority and $\mathrm{P}=0.04$ for superiority). There was significant reduction in rates of CV mortality $(3.7 \%$ vs $5.9 \%)$ and shortened hospitalization due to $\mathrm{CHF}(2.7 \%$ vs $4.1 \%)$. MI was reported in $4.8 \%$ of the empagliflozin group and $5.4 \%$ of the placebo. Stroke was seen in $3.5 \%$ of the empagliflozin group and $3 \%$ of the placebo group. The cardio protective effects of empagliflozin are attributed to changes in arterial stiffness, cardiac function, cardiac oxygen demand, and cardiorenal effects such as reduction in uric acid and albuminuria, and other well-established effects on hyperglycaemia, weight, visceral adiposity, and blood pressure. $^{11}$

\section{Efficacy of empagliflozin on renal outcomes}

Diabetes is one of the leading causes of chronic kidney disease (CKD) worldwide and about $22-40 \%$ of the diabetic subjects are prone to the development of CKD or renal impairment. Reduction of interglomerular pressure reduces proximal tubular sodium re-absorption, delivering increased sodium to macula densa which attenuates tubuloglomerular feedback. Other effects include decreased arterial stiffness and vascular resistance, decrease in serum uric acid and renal neurohormonal mechanism. These may be responsible for improved renal outcomes. ${ }^{18,19}$

In the EMPA-REG outcome trial, the administration of 10 and $25 \mathrm{mg}$ of empagliflozin among patients with estimated glomerular filtration rate $(\mathrm{eGFR})<30 \mathrm{ml} / \mathrm{min} / 1.73 \mathrm{~m}^{2}$ of body surface area improved renal function. The incidence of nephropathy was observed in $12.7 \%$ (525 of 4124) of empagliflozin group and $18.8 \%$ (388 of 2061) in placebo group. Doubling of serum creatinine was seen in $1.5 \%$ (70 of 4645) of empagliflozin group and 2.6\% (60 of 2323) of placebo group. The RRT was started in $0.3 \%$ (13 of 4687) of empagliflozin and $0.6 \%$ (14 of 2333) of placebo group. However, there was no significant difference in the rates of albuminuria. ${ }^{20}$ Therefore the administration of empagliflozin may be associated with improvement in long-term renal outcomes. However, further investigations are required to establish the use of empagliflozin in improving long-term renal outcomes.

\section{SAFETY AND TOLERABILITY}

The most commonly reported adverse effects were an increased incidence of hypoglycemia, urinary tract infection (UTI), genital infection and volume depletion. The incidence of volume depletion was increased in older age group patients than the younger age group patients. ${ }^{21}$

Table 1: Comparison of SGLT2 inhibitors for the treatment of type II diabetes. ${ }^{20,27-31}$

\begin{tabular}{|c|c|c|c|}
\hline $\begin{array}{l}\text { Name of the } \\
\text { drug }\end{array}$ & Canagliflozin & Empagliflozin & Dapagliflozin \\
\hline $\begin{array}{l}\text { Dosage and } \\
\text { frequency }\end{array}$ & $\begin{array}{l}100 \mathrm{mg} \text { once daily in patients } \\
\text { who have an e-GFR of } 45 \text { to less } \\
\text { than } 60 \mathrm{~mL} / \mathrm{min} / 1.73 \mathrm{~m}^{2} \\
300 \mathrm{mg} \text { once daily in patients } \\
\text { tolerating } 100 \mathrm{mg} \text { once daily who } \\
\text { have an e-GFR of } 60 \mathrm{~mL} / \mathrm{min} / 1.73 \\
\mathrm{~m}^{2} \text { or greater and require } \\
\text { additional glycaemic control }\end{array}$ & $\begin{array}{l}10 \mathrm{mg} \text { once daily, taken in the } \\
\text { morning, with or without food } \\
\text { Dose may be increased to } 25 \mathrm{mg} \\
\text { once daily }\end{array}$ & $\begin{array}{l}5 \mathrm{mg} \text { once daily, taken in the } \\
\text { morning, with or without food } \\
\text { Dose can be increased to } 10 \\
\text { mg once daily in patients } \\
\text { tolerating dapagliflozin who } \\
\text { require additional glycaemic } \\
\text { control }\end{array}$ \\
\hline $\begin{array}{l}\text { Names of } \\
\text { major trials }\end{array}$ & $\begin{array}{l}\text { CANVAS } \\
\text { CANVAS-R } \\
\text { CANTATA } \\
\text { CANTATA-SU } \\
\text { CANTATA-D } \\
\text { CANTATA-D2 } \\
\text { CANTATA-MSU }\end{array}$ & $\begin{array}{l}\text { EMPA-REG OUTCOME } \\
\text { EMPEROR-Preserved } \\
\text { EMPEROR-Reduced }\end{array}$ & $\begin{array}{l}\text { DECLARE-TIMI58 } \\
\text { DAPHNIS Study } \\
\text { DECIDE Study }\end{array}$ \\
\hline $\begin{array}{l}\text { Cardiovascular } \\
\text { outcome } \\
\text { benefit }\end{array}$ & Not proven & $\begin{array}{l}\text { Reduce the risk of } \\
\text { cardiovascular death in adult } \\
\text { patients with type } 2 \text { diabetes } \\
\text { mellitus and established } \\
\text { cardiovascular disease }\end{array}$ & $\begin{array}{l}\text { Evidence from observational } \\
\text { studies exist }\end{array}$ \\
\hline $\begin{array}{l}\text { Renal outcome } \\
\text { benefit }\end{array}$ & Not proven & $\begin{array}{l}\text { Studies have shown } \\
\text { improvements in renal outcomes }\end{array}$ & Not proven \\
\hline $\begin{array}{l}\text { Cost of drug } \\
\text { (per tablet) }\end{array}$ & $\begin{array}{l}100 \text { mg-Rs. 55/- } \\
300 \text { mg-Rs. 120/- }\end{array}$ & $\begin{array}{l}10 \text { mg-Rs. 43/- } \\
25 \text { mg-Rs. 52/- }\end{array}$ & $\begin{array}{l}5 \text { mg-Rs. 45/- } \\
10 \text { mg-Rs. 50/- }\end{array}$ \\
\hline
\end{tabular}


Table 2: Ongoing Clinical trials with Empagliflozin. ${ }^{26}$

\begin{tabular}{|c|c|c|c|c|}
\hline Study title & $\begin{array}{l}\text { Clinical } \\
\text { trials.gov } \\
\text { identifier }\end{array}$ & $\begin{array}{l}\text { Intervention/co } \\
\text { mparator }\end{array}$ & Primary outcome & $\begin{array}{l}\text { Current } \\
\text { status of } \\
\text { trial/phase }\end{array}$ \\
\hline $\begin{array}{l}\text { Empagliflozin impact on } \\
\text { haemodynamics in patients with } \\
\text { diabetes and heart failure } \\
\text { (EMBRACE-HF) }\end{array}$ & NCT03030222 & $\begin{array}{l}\text { Empagliflozin } \\
10 \mathrm{mg} / \text { placebo }\end{array}$ & $\begin{array}{l}\text { To compare the change in } \\
\text { pulmonary artery diastolic pressure } \\
\text { from baseline to end of treatment } \\
\text { period between empagliflozin and } \\
\text { placebo }\end{array}$ & $\begin{array}{l}\text { Recruiting } \\
\text { participant } \\
\text { s/Phase IV }\end{array}$ \\
\hline $\begin{array}{l}\text { Effects of empagliflozin on } \\
\text { clinical outcomes in patients } \\
\text { with acute decompensated heart } \\
\text { failure (EMPA-RESPONSE) }\end{array}$ & NCT03200860 & $\begin{array}{l}\text { Empagliflozin } \\
\text { 10mg/ placebo }\end{array}$ & $\begin{array}{l}\text { Change in dyspnoea on VAS } \\
\text { analogue scale (AUC), weight } \\
\text { change from baseline per } 40 \mathrm{mg} \text { of } \\
\text { Furosemide equivalent, hospital } \\
\text { stay of Index admission } \\
\text { Change in NTproBNP }\end{array}$ & $\begin{array}{l}\text { Not yet } \\
\text { open for } \\
\text { participant } \\
\text { recruitment } \\
\text { /Phase II }\end{array}$ \\
\hline $\begin{array}{l}\text { Empagliflozin outcome trial in } \\
\text { patients with chronic heart } \\
\text { failure with reduced ejection } \\
\text { fraction (EMPEROR-Reduced) }\end{array}$ & NCT03057977 & $\begin{array}{l}\text { Empagliflozin } \\
\text { placebo }\end{array}$ & $\begin{array}{l}\text { Composite primary endpoint - Time } \\
\text { to first event of adjudicated CV } \\
\text { (Cardiovascular) death or } \\
\text { adjudicated HHF (Hospitalisation } \\
\text { for Heart Failure) in patients with } \\
\text { Heart Failure with reduced Ejection } \\
\text { Fraction (HFrEF) }\end{array}$ & $\begin{array}{l}\text { Recruiting } \\
\text { participant } \\
\text { /Phase III }\end{array}$ \\
\hline $\begin{array}{l}\text { Empagliflozin outcome trial in } \\
\text { patients with chronic heart } \\
\text { failure with preserved ejection } \\
\text { fraction (EMPEROR-Preserved) }\end{array}$ & NCT03057951 & $\begin{array}{l}\text { Empagliflozin } \\
\text { placebo }\end{array}$ & $\begin{array}{l}\text { Composite primary endpoint - Time } \\
\text { to first event of adjudicated CV } \\
\text { (Cardiovascular) death or } \\
\text { adjudicated HHF (Hospitalisation } \\
\text { for Heart Failure) in patients with } \\
\text { Heart Failure with preserved } \\
\text { Ejection Fraction (HFpEF) }\end{array}$ & $\begin{array}{l}\text { Recruiting } \\
\text { participant } \\
\text { /Phase III }\end{array}$ \\
\hline $\begin{array}{l}\text { Empagliflozin in heart failure: } \\
\text { diuretic and cardio-renal effects } \\
\text { (EMPA) }\end{array}$ & NCT03027960 & $\begin{array}{l}\text { Empagliflozin } \\
\text { placebo }\end{array}$ & $\begin{array}{l}\text { Determine if acute SGLT2 } \\
\text { inhibition will improve the } \\
\text { natriuretic effect of a loop diuretic } \\
\text { compared to placebo. } \\
\text { Measuring the natriuretic effect of a } \\
\text { loop diuretic (placebo v acute } \\
\text { SGLT2 inhibition) via urine sodium } \\
\text { output }\end{array}$ & $\begin{array}{l}\text { This study } \\
\text { is enrolling } \\
\text { participant } \\
\text { by } \\
\text { invitation } \\
\text { only/ } \\
\text { Phase II }\end{array}$ \\
\hline $\begin{array}{l}\text { Empagliflozin in heart failure } \\
\text { patients with reduced ejection } \\
\text { fraction (Empire HF) }\end{array}$ & NCT03198585 & $\begin{array}{l}\text { Empagliflozin } \\
\text { 10mg placebo }\end{array}$ & $\begin{array}{l}\text { Change in plasma concentrations of } \\
\text { NT-proBNP }\end{array}$ & $\begin{array}{l}\text { Recruiting } \\
\text { participant } \\
\text { /Phase II }\end{array}$ \\
\hline $\begin{array}{l}\text { Empagliflozin versus placebo } \\
\text { on the rate of arrhythmic events } \\
\text { in heart failure patients (ERA- } \\
\text { HF) }\end{array}$ & NCT03271879 & $\begin{array}{l}\text { Empagliflozin } \\
10 \mathrm{mg}\end{array}$ & $\begin{array}{l}\text { PVCs burden is defined as the } \\
\text { PVCs percentage of all beats in a } \\
\text { pre-specified period captured on } \\
\text { ICD or CRTD/P device } \\
\text { The change in PVC burden between } \\
\text { time on treatment arm versus time } \\
\text { on placebo will be calculated and } \\
\text { serve as the primary endpoint }\end{array}$ & $\begin{array}{l}\text { This study } \\
\text { is not yet } \\
\text { open for } \\
\text { participant } \\
\text { recruitment } \\
\text { /Phase IV }\end{array}$ \\
\hline
\end{tabular}

Pooled analysis of Phase I-III clinical trials demonstrated favourable benefit-risk profile of empagliflozin in patients with T2DM. ${ }^{22}$ Some of the contraindications associated with empagliflozin include any history of serious hypersensitivity reaction, severe renal impairment, endstage renal disease, or dialysis. Some of the warnings and precautions issued by FDA with respect to empagliflozin include hypotension, ketoacidosis, acute kidney injury, impairment in renal function, urosepsis and pyelonephritis. The use of empagliflozin is not recommended to geriatric patients, and pregnant and lactating women. It remains to be seen if post marketing surveillance data could throw unwelcome surprises regarding the long-term safety of this molecule. $^{23}$ 


\section{CURRENT STATUS}

Empagliflozin has been approved for the treatment of T2DM in adults in the USA, Europe and India. The drug was approved by the FDA and EMA in August 2014 and May 2014 respectively. However, the FDA required post marketing studies on the efficacy of the drug molecule in reducing cardiovascular outcomes. The three SGLT2 inhibitors, dapagliflozin, canagliflozin and empagliflozin have been approved for the treatment of T2DM in adults. However, the safety and efficacy of SGLT2 inhibitors for the treatment of type I diabetes is yet to be established and FDA has not approved the drug for the same. There is limited data comparing empagliflozin with other SGLT-2 inhibitors such as dapagliflozin and canagliflozin that are used to treat T2DM. Data from clinical studies have shown similar reductions in $\mathrm{HbA1c}$, body weight, FPG and blood pressure. Compared to dapagliflozin and canagliflozin, empagliflozin has a higher selectivity for SGLT2. A comparison of SGLT2 inhibitors have been shown in Table $1 .^{23-25}$ The success of empagliflozin in the EMPAREG outcomes study has garnered a lot of attention with this molecule and currently as many as 48 trials are listed as ongoing or upcoming in Clinicaltrials.gov (Table 2). ${ }^{26}$

\section{CONCLUSION}

Empagliflozin, a highly selective SGLT-2 inhibitor, is an effective anti-diabetic drug that has been approved in USA, Europe and India for the treatment of T2DM among adults. The drug has been shown to work as mono therapy and also in combination with the existing OHAs and insulin. The results of the recent long-term trials with empagliflozin have yielded gratifying results, with the drug showing a definite advantage in improving both cardiovascular and renal outcomes. With the huge spurt in the number of trials registered with the molecule especially in heart failure and renal disease, it remains to be seen if these additional indications become equally successful. However, the prohibitive cost of the molecule may be a definite dampener in making this a front-line modality of treatment for diabetes in the near future.

\section{Funding: No funding sources \\ Conflict of interest: None declared \\ Ethical approval: Not required}

\section{REFERENCES}

1. Chen L, Magliano DJ, Zimmet PZ. The worldwide epidemiology of type 2 diabetes mellitus- present and future perspectives. Nat Rev Endocrinol. 2011;8(4):228-36.

2. Thrasher J. Pharmacologic Management of Type 2 Diabetes Mellitus: Available Therapies. Am J Cardiol. 2017;120(1S):S4-16.

3. Santos LL, Lima FJC de, Sousa-Rodrigues CF de, Barbosa FT. Use of SGLT-2 inhibitors in the treatment of type 2 diabetes mellitus. Rev Assoc Medica Bras. 2017;63(7):636-41.
4. Filippatos TD, Liberopoulos EN, Elisaf MS. Dapagliflozin in patients with type 2 diabetes mellitus. Ther Adv Endocrinol Metab. 2015;6(1):29-41.

5. Fujita Y, Inagaki N. Renal sodium glucose cotransporter 2 inhibitors as a novel therapeutic approach to treatment of type 2 diabetes: Clinical data and mechanism of action. J Diabetes Investig. 2014; 5(3):265-75.

6. Munir KM, Davis SN. Differential pharmacology and clinical utility of empagliflozin in type 2 diabetes. Clin Pharmacol Adv Appl. 2016;8:19-34.

7. Wood IS, Trayhurn P. Glucose transporters (GLUT and SGLT): expanded families of sugar transport proteins. Br J Nutr. 2003; 89(1):3-9.

8. Roden M, Weng J, Eilbracht J, Delafont B, Kim G, Woerle HJ, et al. Empagliflozin monotherapy with sitagliptin as an active comparator in patients with type 2 diabetes: a randomised, double-blind, placebocontrolled, phase 3 trial. Lancet Diabetes Endocrinol. 2013;1(3):208-19.

9. Tikkanen I, Narko K, Zeller C, Green A, Salsali A, Broedl UC, et al. Empagliflozin reduces blood pressure in patients with type 2 diabetes and hypertension. Diabet Care. 2015;38(3):420-8.

10. Heise T, Seewaldt-Becker E, Macha S, Hantel S, Pinnetti S, Seman L, et al. Safety, tolerability, pharmacokinetics and pharmacodynamics following 4 weeks' treatment with empagliflozin once daily in patients with type 2 diabetes. Diabet Obes Metab. 2013;15(7):613-21.

11. Zinman B, Wanner C, Lachin JM, Fitchett D, Bluhmki E, Hantel S, et al. Empagliflozin, Cardiovascular Outcomes, and Mortality in Type 2 Diabetes. N Engl J Med. 2015;373(22):2117-28.

12. Ferrannini E, Seman L, Seewaldt-Becker E, Hantel S, Pinnetti S, Woerle HJ. A Phase IIb, randomized, placebo-controlled study of the SGLT2 inhibitor empagliflozin in patients with type 2 diabetes. Diabet Obes Metab. 2013;15(8):721-8.

13. Brand T, Macha S, Mattheus M, Pinnetti S, Woerle HJ. Pharmacokinetics of empagliflozin, a sodium glucose cotransporter-2 (SGLT-2) inhibitor, coadministered with sitagliptin in healthy volunteers. Adv Ther. 2012;29(10):889-99.

14. Hadjadj S, Rosenstock J, Meinicke T, Woerle HJ, Broedl UC. Initial Combination of Empagliflozin and Metformin in Patients with Type 2 Diabetes. Diabet Care. 2016;39(10):1718-28.

15. Kovacs CS, Seshiah V, Swallow R, Jones R, Rattunde $\mathrm{H}$, Woerle $\mathrm{HJ}$, et al. Empagliflozin improves glycaemic and weight control as add-on therapy to pioglitazone or pioglitazone plus metformin in patients with type 2 diabetes: a 24-week, randomized, placebo-controlled trial. Diabet Obes Metab. 2014;16(2):147-58.

16. Rosenstock J, Jelaska A, Zeller C, Kim G, Broedl UC, Woerle HJ, et al. Impact of empagliflozin added on to basal insulin in type 2 diabetes inadequately controlled on basal insulin: a 78-week randomized, double-blind, 
placebo-controlled trial. Diabet Obes Metab. 2015;17(10):936-48.

17. Kosiborod M, Cavender MA, Fu AZ, Wilding JP, Khunti K, Holl RW, et al. Lower Risk of Heart Failure and Death in Patients Initiated on Sodium-Glucose Cotransporter-2 Inhibitors Versus Other GlucoseLowering Drugs: The CVD-REAL Study (Comparative Effectiveness of Cardiovascular Outcomes in New Users of Sodium-Glucose Cotransporter-2 Inhibitors). Circulation. 2017; 136(3):249-59.

18. Skrtić M, Yang GK, Perkins BA, Soleymanlou N, Lytvyn Y, von Eynatten M, et al. Characterisation of glomerular haemodynamic responses to SGLT2 inhibition in patients with type 1 diabetes and renal hyperfiltration. Diabetol. 2014;57(12):2599-602.

19. Cherney DZI, Perkins BA, Soleymanlou N, Maione M, Lai V, Lee A, et al. Renal hemodynamic effect of sodium-glucose cotransporter 2 inhibition in patients with type 1 diabetes mellitus. Circulation. 2014;129(5):587-97.

20. Wanner C, Inzucchi SE, Lachin JM, Fitchett D, von Eynatten M, Mattheus M, et al. Empagliflozin and Progression of Kidney Disease in Type 2 Diabetes. N Engl J Med. 2016;375(4):323-34.

21. Shiba T, Ishii S, Okamura T, Mitsuyoshi R, Pfarr E, Koiwai K. Efficacy and safety of empagliflozin in Japanese patients with type 2 diabetes mellitus: A subanalysis by body mass index and age of pooled data from three clinical trials. Diabetes Res Clin Pract. 2017; 131:169-78.

22. Kohler S, Zeller C, Iliev H, Kaspers S. Safety and Tolerability of Empagliflozin in Patients with Type 2 Diabetes: Pooled Analysis of Phase I-III Clinical Trials. Adv Ther. 2017;34(7):1707-26.

23. Highlights of prescribing information. These highlights do not include all the information needed to use JARDIANCE safely and effectively, 2016. Available at: https://www.accessdata.fda.gov/drugsatfda_docs/labe 1/2016/204629s008lbl.pdf. Accessed 6 November 2017.

24. Highlights of prescribing information. These highlights do not include all the information needed to use FARXIGA safely and effectively, 2014. Available at:https://www.accessdata.fda.gov/drugsatfda_docs/la bel/2014/202293s000lbl.pdf. Accessed 6 November 2017.

25. Highlights of prescribing information. These highlights do not include all the information needed to use INVOKANA® safely and effectively, 2017. Available at: https://www.invokana.com/prescribinginformation.pdf. Accessed 6 November 2017.

26. ClinicalTrials.gov. Available at: https://clinicaltrials.gov/ct2/results?term=Empagliflo zin. Accessed 6 November 2017.

27. Neal B, Perkovic V, Mahaffey KW, de Zeeuw D, Fulcher G, Erondu N, et al. Canagliflozin and Cardiovascular and Renal Events in Type 2 Diabetes. N Engl J Med. 2017;377(7):644-57.

28. Plosker GL. Canagliflozin: a review of its use in patients with type 2 diabetes mellitus. Drugs. 2014;74(7):807-24.

29. Minze MG, Will K, Terrell BT, Black RL, Irons BK. Benefits of SGLT2 Inhibitors beyond glycemic control - A focus on metabolic, cardiovascular, and renal outcomes. Curr Diabet Rev. 2017.

30. Kumana CR, Tan KCB, Cheung BMY. Absolute benefits of empagliflozin in type 2 diabetes: a game changer? Postgrad Med J. 2017;93(1101):373-5.

31. Fioretto P, Avogaro A. Dapagliflozin: potential beneficial effects in the prevention and treatment of renal and cardiovascular complications in patients with type 2 diabetes. Expert Opin Pharmacother. 2017;18(5):517-27.

Cite this article as: George M, Srinivas K, Damal KS. Empagliflozin: an exciting prospect in the treatment of diabetes. Int J Basic Clin Pharmacol 2018;7:1-6. 